\title{
THE GRIEF HERITAGE OF THE OTTOMAN BOSNIA AND HERZEGOVINA
}

\author{
Tülay Polat Üzümc ̈̈ ${ }^{1}$ \\ İbrahim Çetin \\ Ersin Ŭgurkan
}

\begin{abstract}
The whole of the soceites havehappiness and proudly remembered events in the past, at the same time that has got the period is remembered with pain and sorrow. The grief of that event to visit the places now, search for the traces of the historical background, nationality, religion or community to share the pain of the cultural ties that desire has led to the grief tourism today. Tourism literature; dark, grief, thane, morbid, death, war and so on. grief associated with names tourism, has been used in the marketing of a new type of tourism destinations as a travel motivation. The war in Bosnia-Herzegovina between 1992-1995 year in Europe. That is the greatest human tragedy after the Second World war Indeed, Bosnia and Herzegovina, There was an ethnic cleansing and genocide and 26.02. 2007 International Court of Justice massacres committed against Bosniaks in Srebrenica in Bosnia and Herzegovina has been described as genocide. Although tourism has significant potential, Bosnia and Herzegovina's state system accommodates a problem in terms of griefness tourism. The Bosnian Serb Republic and the grief of local governments in the region in terms of tourism activity seen in front of or opposed to symbolic elements. In this context, our work; primarily related literature scanning, Bosnia and Herzegovina will be given conceptual information about the traces of war, then griefness in the document of Bosnia and Herzegovina tourism centers will be evaluated on the basis of photos and observations. It will also focus on the importance and differences in comparison with the grief came into prominence in world tourism destinations. As a result, Bosnia and Herzegovina, grief tourism potential of putting forward for Bosnia and Herzegovina will be presented recommendations for addressing the importance and contribution.
\end{abstract}

Key words: Bosnia and Herzegovina, Grief/Dark Tourism, War, Tourism

\section{INTRODUCTION}

Tourism, untill reaching current days, referred as an activity either leisure or donefor the purpose of pilgrimage, health, sport, business, cultural, historical and as special interest etc. Although these forms of tourismcontinues to increase, tourists are increasingly searchingfor different experiences. The motives of the tourists are becoming more divesified than the usual mass tourist experiences which content to loll on the beach of large scale resort hotels, and usual communication with the visitors and

\footnotetext{
${ }^{1}$ Assistant Professor, Kocaeli University, Kartepe Tourism Vocational School, Kartepe, Kocaeli, Turkey. e-mail: tulayuzumcu@hotmail.com
} 
environment. As Robb(2009) interpreted the experiences of many of today's tourists were no longer content to loll on the beach or gatheraround the hotel bar with other visitors and tourists increasingly seek tounderstand other cultures and histories in ways that transcend the sanitizedversion of reality that tourism had traditionally offered. As a result, placesof human misery and death had become the focus of sizable touristic interest, whether standing on their own as destinations or as a part of largeritineraries. This type of tourist practices involving visiting destinations atwhich violence is the main attraction and it is called as dark tourism. According to the Robb(2009) dark focused tours were usually undertaken in thename of social justice and historical awareness to learn more about violence in the hope of preventingfuture atrocities or ending current ones. The recognition of tourism's role in the processes of dark tourism concept can help provide a better understandingand remember the undemanded events happened in the past and reconstruction of the past with the understanding of all humanity.

Dark tourism as a 'thanatoptic tradition' has a long history, emerging from the contemplation of death that goes back to the Middle Ages and intensified during the late eighteenth and early nineteenth centuries with visits to places giving different sensation to the visitors. The core of the term is accepted as thanatourism in the literature that is the 'travel dimension of thanatopsis', defined as 'travel to a location wholly, or partially, motivated by the desire for actual or symbolic encounters with death, particularly, but not exclusively, violent death' (Seaton 1996:240). From the diaries recorded and memories, in the past, 1770-1830 in Europe, there was a travel which included thanatoptic elements, visits to locations of death and violence, both contemporary and historical, including castles, prisons, graveyards, battlefields and public executions(Seaton, 1996:239). "Deaths, disasters, carnage and atrocities in touristic form are becoming an increasingly pervasive feature within the contemporary tourism landscape, and as such, are ever more providing potential spiritual journeys for the tourist who wishes to gaze upon real and recreated death. (Verma and Jain, 2013: 13).However, it seems from the grief tourism practices, the day-to-day affinity and level of awareness of the events are the drivers of tourists to the center of attraction as the grief tourism destination. Behavioural phenomenon of tourists' motives, and 'continuum of intensity' exists dependent upon the differing motives for visiting a site and the extent to which the interest in death is general or person-specific. Also dark travel activity is separated into five possible categories by Seaton(1996) including: to witness public enactments of death; to sites of individual or mass deaths; to memorials or internment sites; to see symbolic representations of death; and, to witness reenactments of death(Seaton (1996:240-2), Rojek(1993) refers to that notion or behavioral phenomenon the postmodern spectacles, repeated reconstructions that were dependent on modern audio-visual media for their's continued popularity.

There are sad and painful happenings which even do not want to be remembered in the past of every society. Tourism activities carried out to remember these sad events, show respect to the casualties, or fulfill the haj duty is called grief tourism. Grief tourism is a 
type of heritage tourism which is also called as cultural heritage tourism. In this context, grief tourism is a type of tourism involving trip to such places where death events such as torture or genocide happened, and to monuments and museums built in the name of such events, and to places where painful events such asnatural disasters happened. These areas for grief tourism make visitors feel the past events today with the grief they arouse and make them feel deep rooted and belonging to that place(K1lıç et al, 2011). The war which took place in Bosnia-Herzegovina in 1992-95 is one of the examples for dark tourism.

In this context, the areas where the war took place in 1992 in BosniaHerzegovina;Srebrenica genocide locations,Preijedor concentration camp, the Hope Tunnel, the war museum, houses and streets where bullet marks can still be seen, Mostar Bridge, Suada Bridge, Markale Masaccre, Ahmici massacre, A monument to the dead children in Sarajevo, Massacres in Visegrad and Foca, Drina Bridge, Latin Bridge, The Memorial "Eternal flame", Vijećnica, the National Library of Bosnia and Herzegovina, Alija Izetbegovic Museum and Tomb of Alija Izetbegovic, Museum of Crimes Against Humanity and many other places can be seen and painful stories can be unfortunately witnessed. Unfortunately, in Bosnia-Herzegovina is one of the most important grief tourism centers which carries the marks ofthe war which took place when the technology and the civilization was welldeveloped in the world.

\section{LITERATURE REVIEW}

Rojek (1993) first introduced the notion of dark attractions with the concept of 'Black Spots', as the developments of grave sites and sites in which celebrities or large numbers of people have met with sudden and violent death(Rojek,1993:136). And Rojek(1993) refers this with the postmodern spectacles, repeated reconstructions that are dependent on modern audio-visual media for their continued popularity. Rojek commences his analysis by referring the to the hordes of sightseers flocking to the sites of disasters(Stone and Sharpley, 2008:577). Also some sites are categorized as "nostalgic" by distinguishing disaster sites analytically distinctive from Black Spots as sensation sites. A different term for the notion used as "morbid tourism" by Blom(2000:32) at the meaning of tourism that 'focuses on sudden death and which quickly attracts large numbers of people' and, 'an attraction-focused artificial morbidity-related tourism' commented quite complex and distinctive by Ashworth and Hartmann( 2005) and Stone (2006) from different views; First, the immediacy and spontaneity of 'sensation' tourism to death and disaster sites might be compared with premeditated visits to organized sites or events related to near and/or distant historical occurrences. Second, a distinction exists between purposefully constructed attractions or experiences that interpret or recreate events or acts associated with death, and 'accidental' sites such as graveyards or memorials. Third, it was unclear to what extent an 'interest' in death was the dominant reason for visiting dark attractions. Finally, questions might be about why and how the experiences related to dark sites were 
produced or supplied for the different purposes such as politically, for education, entertainment or economic gain (Stone and Sharpley, 2008:577).

The study of dark tourism and its associated destinations is arguably relatively new. Some different number of definitios made regarding the death-related tourist activity concept as mentioned in literature. Seaton(1996), as 'thanatourism", (Blom 2000), 'morbid tourism' (Rojek 1993) 'black-spot' or, as Dann (1994:61) alliterates, 'milking the macabre'. Additionally, attempts have been made to analyse specific manifestations of dark tourism, from war museums adopting both traditional and contemporary museology methods of (re)presentation (Wight and Lennon 2004), to genocide commemoration visitor sites and the political ideology attached to such remembrance (Williams 2004). This subset ofcultural tourism was first coined as "negative sightseeing" by McCanell (1988). Although there isstill some level of debate with regards to the semantics of the "dark" element of dark tourism (e.g. "dark" because it is not a typical sun and fun filled vacation or "dark" as a result of the natüre of the deeds associated with its destinations, including murder and genocide), Bowman and Pezzullo (2010) were the first to explore the terminology used in published research associated with this type of tourism (Liyanage, Stefaniak and Powell, 2015: 283).

This practices led to the foundation of the new direction in the field of tourism - Dark tourism. The concept was coined by the Scottish sociologists J. Lennon and M. Foley in the article "JFK and Dark Tourism: Heart of Darkness", published in a special issue of the International Journal of Heritage Studies in 1996. The concept is just the new word about the very old phenomenon. Other sociologists introduce other concepts such as Black Spots Tourism (Rojek), Morbid Tourism (Bloom), Thanatourism (Seaton), Atrocity Heritage Tourism (Beech), Grief Tourism (Dann) etc. Generally, dark tourism is "the contemporary visitation of people to formal or informal visitor attractions, sites or exhibitions which offer presentation and interpretation of death and associated suffering as their raison d'etre". In other words it may be considered a historical phenomenon - that is, visiting sites or attractions that provide living memory (Rybakova, 2012).

Dark tourism is basically referred to as the act of travel to sites associated with death, suffering or the seemingly macabre' (Stone, 2006:146). Foley and Lennon (1997), define dark tourism as the visitation to any site associated with death, disaster and tragedy in the twentieth century for remembrance, education or entertainment'(Stone, 2010).Macmillan's definition of grief tourist: "a person who travels specifically to visit the scene of a tragedy or disaster". Early forms of death related tourism were the Roman gladiatorial games, pilgrimages or attendance at medieval public executions(Stone and Sharpley, 2008:574) hovewer the term Dark tourism was first used in 1996, when the extension of this phenomenon points out Lennon and Malcolm researchers. Authors Lennon and Foley sought to distinguish between only a "simple" curiousity with past events that involved visitation to sites of past battles, disasters and places and such sites have gained global importance and comprised events that had occurred within living memory (Molokáčová And Molokáč, 2011:2-3). Rojek 
(1993:85) stress and explains the term from the different point of view as fatal attractions' or =black spots' and suggests for commercial developments of grave sites and sites in which celebrities or large numbers of people have met with sudden and violent deaths'(Stone, 2010).Dark tourism is associated with thanatopsis. Thanatopsis (Seaton, 1996) is defined as all the signifying forms of representation, symbolisation and material evidence by which ideas of death are communicated to an individual in time and space within a given society and as the result of mantality thana tourism seeks to establish the philosophical and historical roots of the mentalitd through which the publicly shocking and repugnant may be experienced as a source of private pleasure(Seaton, 1996:234). Grief tourism possesses nostalgic travel motives of tourists visit the places of mass death of the ancestors, as, for instance, the Jew concentration camps or the Holocaust places. Thus, dark tourism can be described as a new tourism trend that overlaps nostalgic, religious, extreme and research types of tourism (Bordun and Komar, 2014:5).

From the fiure 1.1. It seems that different number of thana tourism definitions done by the different authors and it emerges from the above discussion to classify thanatourism are loking complex and hovewer that is stressed from the figüre that the thanatourism categories all possess the commonality of being sites of death or depravity; however they are diverse for a number of reasons.(Dunkley et al, 2007:6) The terms, dark tourism, morbid, macabre, grief tourism are interpreted as the dimensional forms of thana tourism as Seaton (1996) stated. In this study we interpret that dimension as grief tourism. With this respect the form of grief tourism was examined in five forms of thanatourism with the relation of romanticism as follows (Seaton, 1996);

- Travel to witness public enactments of death.

- Travel to see the sites of mass or individual deaths, after they have occurred.

- Travel to internment sites of, and memorials to, the dead.

- Travel to view the material evidence, or symbolic representations of death, in locations unconnected with their occurrence.

- Travel for re-enactments or simulation of death.

Grief tourism currently encompasses a great amount of tourism demand. Unfortunately happenings in the past, currently are the attaction sites for grief tourists. Mass death sites or to sites of very well known and popular individual deaths and other examples the places or houses as the haunts of famous murderers and serial killers are attracking sightseers (Seaton, 1996:241).Gallipoli (Gelibolu) which the size of the human/soldier loss makes the importance of the campaign even bigger is one of the places visited mostly by Anzacs internationaly and Turkish citizens domestically in Turkey. Bosna and Herzegovina is the other location which has a great tragedy in the near past. 
Table 1. An Alternative Thanatourism Framework

\begin{tabular}{|c|c|c|c|c|}
\hline $\begin{array}{l}\text { Seaton (1996) } \\
\text { Five broad categories }\end{array}$ & $\begin{array}{l}\text { Dann } \\
\text { (1998): } \\
\text { Five-fold } \\
\text { model }\end{array}$ & $\begin{array}{l}\text { Ashworth } \\
\text { (2004) Six } \\
\text { Adjectival } \\
\text { tourisms. }\end{array}$ & $\begin{array}{l}\text { Tarlow's } \\
\text { (2005) Seven } \\
\text { Categories }\end{array}$ & $\begin{array}{l}\text { Sharpley's } \\
(2005) \\
\text { Shades of } \\
\text { Grey } \\
\text { Tourism }\end{array}$ \\
\hline $\begin{array}{l}\text { 1.Witnessing public } \\
\text { enactments of death; } \\
\text { 2.Witnessing sites of } \\
\text { mass or individual } \\
\text { deaths, after they have } \\
\text { occurred; } 3 \text {.Witnessing } \\
\text { internment sites of, and } \\
\text { memorials to the dead; } \\
\text { 4.Witnessing the } \\
\text { material evidence, or } \\
\text { symbolic representation } \\
\text { of death, in locations } \\
\text { unconnected with their } \\
\text { occurrence; } \\
\text { 5. Witnessing } \\
\text { reenactments or } \\
\text { simulations of death }\end{array}$ & $\begin{array}{l}\text { 1.Perilous } \\
\text { places; } \\
\text { 2.Houses of } \\
\text { horror; } \\
\text { 3.Fields of } \\
\text { fatality; } \\
\text { 4.Tours of } \\
\text { torment; } \\
\text { 5. Themed } \\
\text { thanos. }\end{array}$ & $\begin{array}{l}\text { 1.War } \\
\text { tourism, } \\
\text { 2.Battlefield } \\
\text { tourism, } \\
\text { 3.Disaster } \\
\text { tourism, } \\
\text { 4.Killing- } \\
\text { fields } \\
\text { tourism } \\
\text { 5.Hot spots } \\
\text { tourism 6. } \\
\text { Atrocity } \\
\text { heritage } \\
\text { tourism. }\end{array}$ & $\begin{array}{l}\text { 1.Pretext to } \\
\text { understanding } \\
\text { our own age } \\
\text { 2.Romanticism } \\
\text { 3.Barbarism } \\
\text { 4. Part of } \\
\text { national } \\
\text { identity } \\
\text { 5. Sign of } \\
\text { decadence } \\
\text { 6. Mystical } \\
\text { experience } \\
\text { 7. Spiritual } \\
\text { experience }\end{array}$ & $\begin{array}{l}\text { 1.Pale } \\
\text { Tourism; } \\
\text { 2.Grey } \\
\text { Tourism } \\
\text { supply; } \\
\text { 3.Grey } \\
\text { Tourism } \\
\text { demand; } \\
\text { 4. Black } \\
\text { tourism. }\end{array}$ \\
\hline
\end{tabular}

Source: Dunkley et al, 2007:6).

\section{Purpose and Methodology}

There have been limited number of studies about grief tourism as a new form of tourism this study considers Bosnia and Herzegovina as a very important destination of for grief tourism.Fort his purpose in the study, literature, archives, visual sources(photo/video) were used as the main material. At the realization of the research, the evaluation of literature data, the scanning of national/international print media and web pages, additionally the evaluation of experience, photographs, documents, oral and written historical information obtained by direct observation is taken as basis.In this study, being a form of a documentarial analysis, the concept of grief tourism and its international use, historical heritage of the Ottoman Empire which is subject to grief tourism in Bosnia and Herzegovina, the dimensions of these heritage in grief tourism and genocide to Bosniaks between 1992-1995 were displayed with figures and documentsin the concept og grief tourism. 


\section{Evaluation of the Sadness Tourism in Bosnia and Herzegovina}

The State of Bosnia-Herzegovina consists of two individual areas including Bosnia and Herzegovina. Bosna is the north of the country containing the cities Srajevo, Travnik and Tuzla etc. while Herzegovina is the area closer to Dalmatia and Adriatic, containing the cities Mostar and Konjic etc. Bosnia is populated mostly by Bosnians and Serbians while it is seen that Herzegovina is predominantly populated by Bosians and Croatians (Özder, 2012).The State of BiH consists of two major Entities, the Federation of Bosnia \& Herzegovina $(\mathrm{FBiH})$ and the Republika Srpska (RS). In turn the $\mathrm{FBiH}$ is divided into ten cantons. Much legal andregulatory authority is at the Entity and canton levels, but the State is gradually acquiring morefunctionality(Rosenbaum, 2006: 2).

Bosnia and Herzegovina annexed by Austria-Hungary after the decisions taken in Berlin in 1878. I. Serb-Croat-Slovene Kingdom after World War II.After World War II came to the sovereignty of Yugoslavia. While declaring its independence in 1991 witnessed the most brutal massacres in human history of the country is covered with many points of the genocide memorial and cemetery. Bosnia and Herzegovina; Bearing deep scars of war all over the country and society in all depth is Europe's most sad country. But it is the country where, despite everything, to live together and must be aware of. Green vegetation, outstanding color raging rivers, bridges. Furthermore The historical heritage dating from the Austro-Hungarian Empire and the Ottoman Empire in Europe is a place where civilizations meet (Malcom, 1999).Also in 1992 and experienced the tragedy of the Bosnian War in 1995, the country's tragedy was caused to the fore with grief tourism.

1992 until the disintegration of Yugoslavia, where many different peoples live in peace and even religious example is shown as a country that Bosnia and Herzegovina (Türkeş, 2012). The result of the massacres reached processed as genocide against Bosniaks with war the country has become almost cemeteries in the country and in places like the Potocari, Bosnian martyrs where thousands of Bosniaks or have emerged cemeteries like the valley monuments or graves at the scene of the massacres. In this way, there are many areas related to sadness tourism in the country. However, due to the country having two structured systems, places to visit on Sadness tourism it is severely restricted. Because the current system in the country that consists Bosnian-Croat Federation and Republic of Serb. Bosnian Serb ultra-nationalism is especially moving in this direction to enter the Serbian local governments in places where there are the remains of the most terrible genocide in the region and to eliminate traces into practice. Bosnian Serb republic has limitations associated with the monument to commemorate the victims in many places being attempted.Nevertheless, the Muslim-Croat Federation in the many monuments and tombs of tourists experienced as evidence of ethnic cleansing in Bosnia, it has many places to go and visit. They are as follows;

1. Suada Bridge: Known as the longest city siege in modern history and 44 months in Sarajevo, one day before the start of the siege of the Serb Democratic Party militia forces massacred Suada Dilberovic and Olga Sucic became the first victims of the siege 
of Sarajevo. In 1992, during a demonstration for peace hit Dubrovnik medical student Suada dedicated to Dilberovic still Bridge Suada with a new name Vrbany formerly adorned with fresh flowers every day (2).

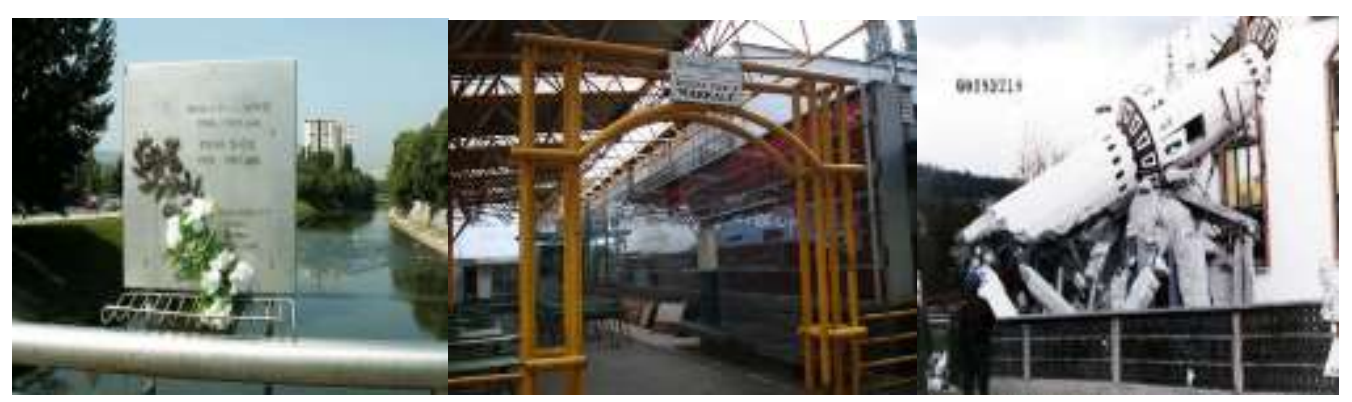

Fig. 1. Suada Bridge

Fig. 2. Markale Masaccre

Fig. 3. Ahmici Massacre

2. Markale Masaccre: The attack to the bazaar in Markele, which was located in the city center, is one of the first massacres that comes to people's minds. During the first attack orchestrated by Serb forces on Feb. 5, 1994, 68 people died and 144 people were injured. On the second attack on Aug. 28, 1994, 43 people lost their lives while 84 were injured (3).

3. Ahmici Massacre: Ahmići massacre was the culmination of the Lašva Valley ethnic cleansing committed by the Croatian Community of Herzeg-Bosnia's political and military leadership on Bosnian Muslim (Bosniak) civilians during the Bosnian War in April 1993. It is the biggest massacre committed during the conflict between Croats and the Bosnian government (dominated by Bosniaks). The International Criminal Tribunal for the former Yugoslavia in The Hague has ruled that these crimes amounted to crimes against humanity in numerous verdicts against Croat political and military leaders and soldiers, most notably Dario Kordić, political leader of Croats in Central Bosnia who got 25 years in prison. The massacre was discovered by United Nations drawn from the British Army, under the command of Colonel Bob Stewart(4).

4. A Monument To The Dead Children in Sarajevo: A monument to the dead children in Sarajevo was inaugurated in May 2009. At the opening ceremony of the thousands of people came. This monument is dedicated to the child victims of the civil war of the 1990s. Copper pedestal is installed in the fountain and made of numerous fused shells.. Many children during the 44-month siege of Sarajevo were killed by shots of snipers. Two glass shape of the monument is made of glass, they symbolize the mother and child. Around the fountain there is a metal ring, on which are visible the footprints of the brothers and sisters of the deceased. On the creation of the monument took about six tons of melted bullet shells and mortar shells collected after the shelling of the city by Serbian forces (5). 


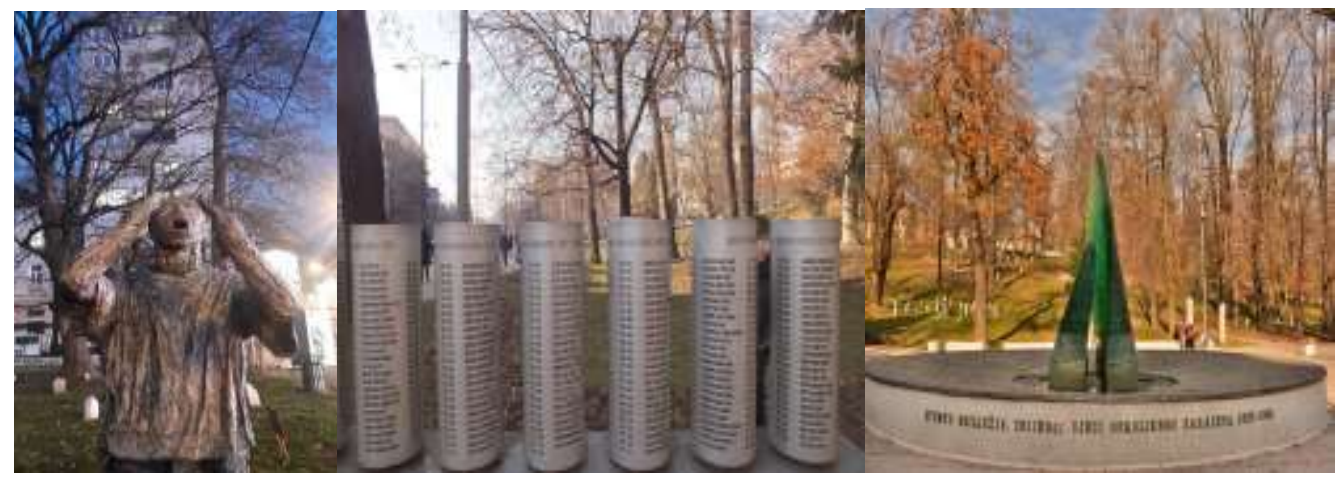

Fig. 4-5-6. A Monument To The Dead Children in Sarajevo

5. Tunnel of Hope/ Sarajevo Tunnel: It truly is a result of hard work by people who wanted to find creative ways to survive during the war. Sarajevo was under siege during the Bosnian war from 1992 to 1995. During this time, Sarajevo was occupied by Serbia and the region close to the airport was under United Nations control. In order to connect two cities that are cutoff due to the siege, a tunnel was built in secret. The area was under 24 hour shelling from Republika Srpska forces so the construction of the tunnel had to be done in absolute secrecy. The purpose of this was to allow food, war supplies, humanitarian aid, and for people to cross. This was also a way to transport arms to bypass the arms embargo. It connected two Bosnian held territories, Dobrinja and Butmir. The plan for this tunnel was done by a Bosnian engineer and it went under the airport. Due to lack of supplies, this tunnel was dug by hand and showels, and they were paid for their work with a pack of cigerrates, which was a rare commodity in those days. The construction of the tunnel finished on 30th June 1993 and it was operational the day after(6).

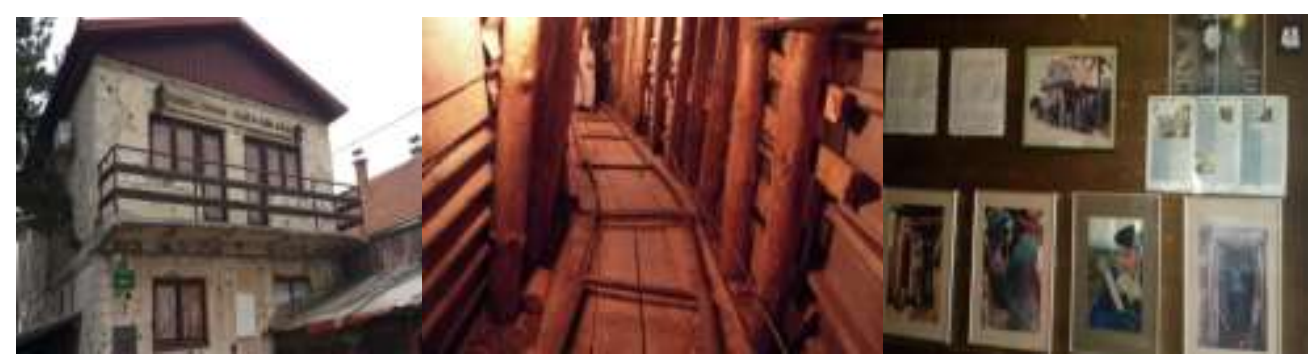

Fig. 7-8-9. Tunnel of Hope (Sarajevo Tunnel)

6. Massacres in Visegrad and Foca: Another city that witnessed huge massacres was Visegrad. Although the city was intensely inhabited by Bosnians, the Bosnian community became the minority in the region following the war. In Visegrad, Serb troops massacred, tortured and expatriated 1,700 people, and 14,000 people had to abandon their homes. Very few people were able to survive this massacre (7). The Bosnians living in Foca, which was previously known as Srbinje (the city of Serbs), 
experienced ethnic cleansing, mass murder and torture throughout the war. As a result of the mass murders in Foca, 1,900 Bosnians are presumed dead and 850 Bosnians are still missing (8).

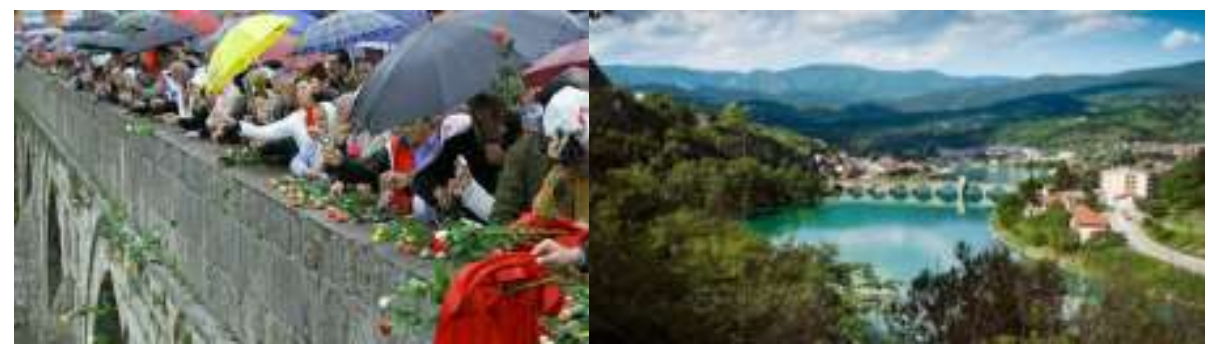

Fig. 10. Massacres in Visegrad

Fig. 11. Drina Bridge

Drina Bridge:The bridge on the Drina is a heritage of the great vizier Mehmed pasa Sokolovic (in Turkish Sokollu Mehmet Paşa, 1505 or 1506-1579). He is one of the great Osman war generals by origin from Bosnia. He was born in the village of Sokolovići near Rudo in 1505. or 1506, and was a child of Orthodox parents. He would become the officer of the Osman army for his skills, and on top of his rule he became a great vizier. At the highest peak of his rule, he orders to build the bridge on Drina at Višegrad that no other bridge looks alike. The bridge was built in the period from 1571 to 1577 by at that time the most famous Turkish architect Kodža Mimar Sinan.

7. The Srebrenica Genocide: Eight thousand Bosnian Muslim men and boys were killed over four days in July 1995 by Bosnian Serb death squads after they took the besieged town, which had been designated a "safe area" under the protection of UN troops (9).The Srebrenica Massacre, which is also commonly known was the Srebrenica Genocide, was the genocide of approximately 8,732 Bosniak men and children in Srebrenica in Bosnia. It was committed by the Army of Republika Srpska during the Bosnian War and was the worst act of mass murder in Europe since WWII. Around 6505 victims of the massacre have been identified thanks to DNA analysis (10).

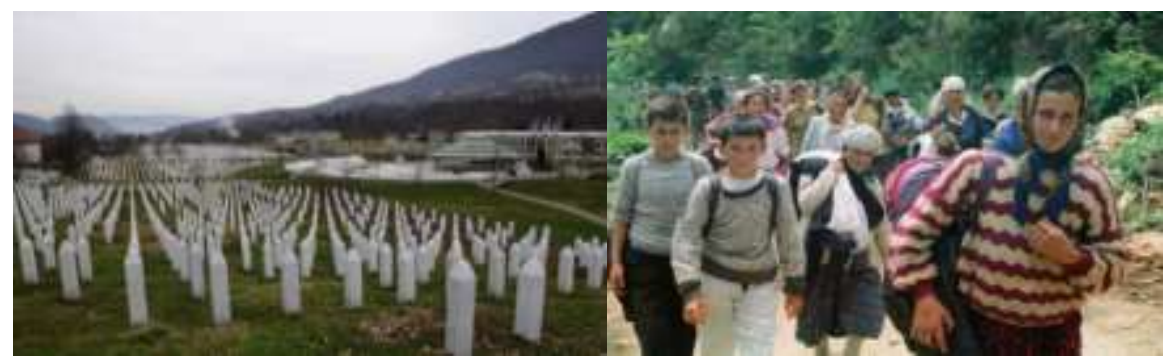

Fig. 12-13. The Srebrenica Genocide

8. Concentration Camp of Prijedor: According to the 1991 census, Opstina Prijedor had a total population of 112,470 people, of whom 44 per cent were Muslims, 42.5 per cent Serbs, 5.6 per cent Croats, 5.7 percent Yugoslavs and 2.2 per cent others 
(Ukrainians, Russians and Italians). In early April 1992, the total population may have been approximately 120,000 people, augmented, inter alia, by an influx of people who had fled the destruction of their villages in areas to the west of Opstina Prijedor (11).Many concentration camp was established by the Serb army around Prijedor. These are; The Trnopolje camp was a concentrationcamp established by Bosnian Serb military and police authorities in the village of Trnopolje near Prijedor in northern Bosnia. From 1990-1992, the Omarska mine in Prijedor, Bosnia was used as a concentrationcamp by Bosnian Serb forces. the Manjaca concentrationcamp near Prijedor, north-west Bosnia, where Serbs interned, tortured, raped, and killed thousands of Bosniaks (Bosnian Muslims) (12).

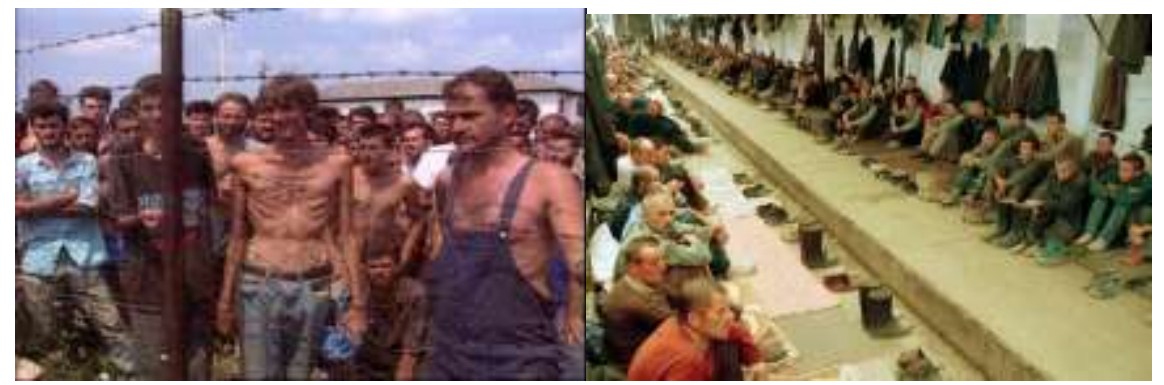

Fig.14-15: Concentration Camp of Prijedor

9. Latin Bridge: 4 arched stone bridge in Sarajevo is called the Latin Bridge. 16th century bridge was built by the famous Sarajevo assassination is famous. Latin Bridge is a historic Ottoman bridge over the River Miljacka in Sarajevo, Bosnia and Herzegovina. The northern end of the bridge was the site of the assassination of Archduke Franz Ferdinand of Austria by Gavrilo Princip in 1914, which became a casus belli of World War I. That the assassination took place at the entrance of the bridge there is a plaque on the wall of the building into the incident. Also this bridge divides Sarajevo (13).

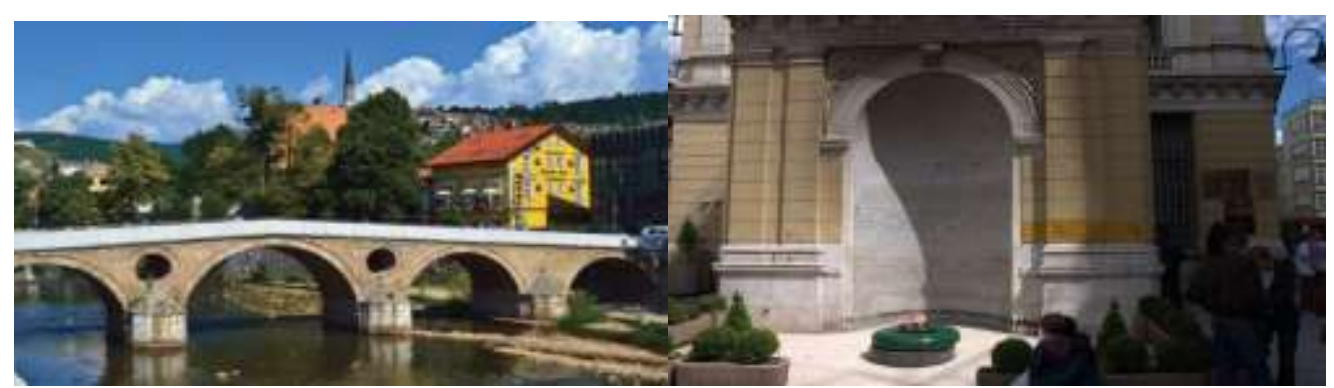

Fig. 16. Latin Bridge

Fig. 17. The Memorial "Eternal Flame"

10. The Memorial "Eternal Flame": The memorial "Eternal flame" in Sarajevo is located at the intersection of Avenue of Marshal Tito street Ferhadija. This monument was built in memory of those killed during the Second world war. It was established in 
April 1946, on the occasion of the first anniversary of the liberation of the city from the German invaders. The memorial "Eternal flame" in Sarajevo is located in the city centre. It is dedicated to the victims of the Second world war, defending Yugoslavia from the Nazis. In the month long siege of Sarajevo in the early 1990s, the flame of the memorial was closed because of lack of fuel. The main Avenue in the city called by the name of Marshal Tito. It is near the "Eternal fire," he converges with street Ferhadija is the most convenient place for a stroll from the Old town in the Central district(14).

11. Vijećnica, the National Library of Bosnia and Herzegovina: The building was built in 1892-1894 after plans by the Austrian architect Alexander Wittek as a Town Hall. It is considered one of the most important examples of the so-called pseudo Moorish style. The Austro Hungarian Archduke, Franz Ferdinand visited the City Hall of Sarajevo on June 28, 1914, between the first assassination attempt aimed at him and the second, fatal attack. Since 1947, the building was used as a national and University Library.At the siege of Sarajevo during the Bosnian war (1992-1995), the library was badly damaged in the night from 25 to 26 August 1992. More than 2 million books and documents were burned. Under the direction of architect Nedžad Mulaomerović, the building, with funding of the EU in 1996 was rebuilt and restored. Photos from private collections helped the reconstruction made of previous visitors. Other documents found in archives in Vienna, Budapest and Belgrade. In the Hungarian Zsolnay porcelain factory, which had made it the original tiles on the facade found whose original, hand painted templates. Also the new tiles were produced by Zsolnay. The reconstructed Vijećnica was opened in May 2014. She will accommodate future parts of the city administration, the National Library and a Café (15).

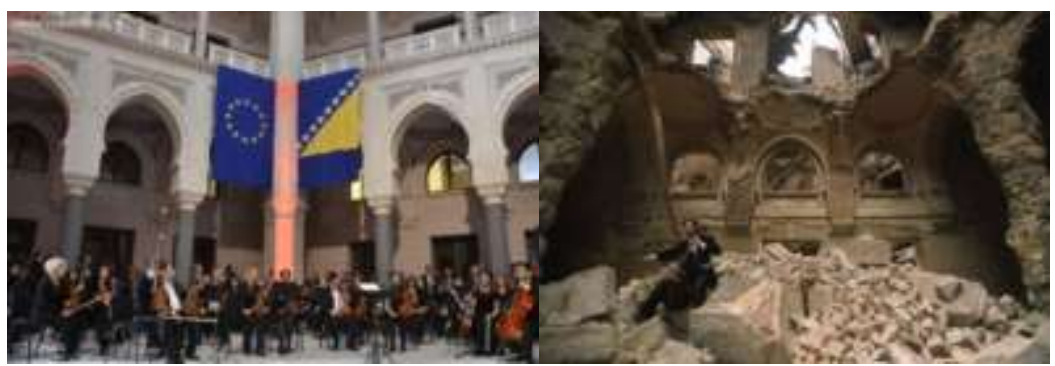

Fig. 18-19. Vijećnica, The National Library of Bosnia and Herzegovina

\section{Alija Izetbegovic Museum and Tomb of Alija Izetbegovic(Alifakovac Muslim Cemetery)}

Alija Izetbegović's grave in Sarajevo. Alija Izetbegovic's tomb in Sarajevo on Kovaçi cemetery (16)and there are also 1700 martyrs in the cemetery. Open since 2007, Alija Izetbegovic Museum is located in the old town, near Martyrs' Memorial Cemetery Kovaci in Sarajevo. This museum/monument, erected with the help of Izetbegovic's many admirers, reveals the never-to-be-forgoten story of Bosnia and Herzegovina. The 
permanent exhibition displays the artworks of Alija Izetbegović, which tell the story of Bosnia and Herzegovina (17).

13. Museum of Crimes Against Humanity: The Museum of Crimes Against Humanity and Genocide 1992-1995 has opened in Sarajevo, displaying the personal belongings of victims among exhibits exploring Bosnia's wartime history(18).

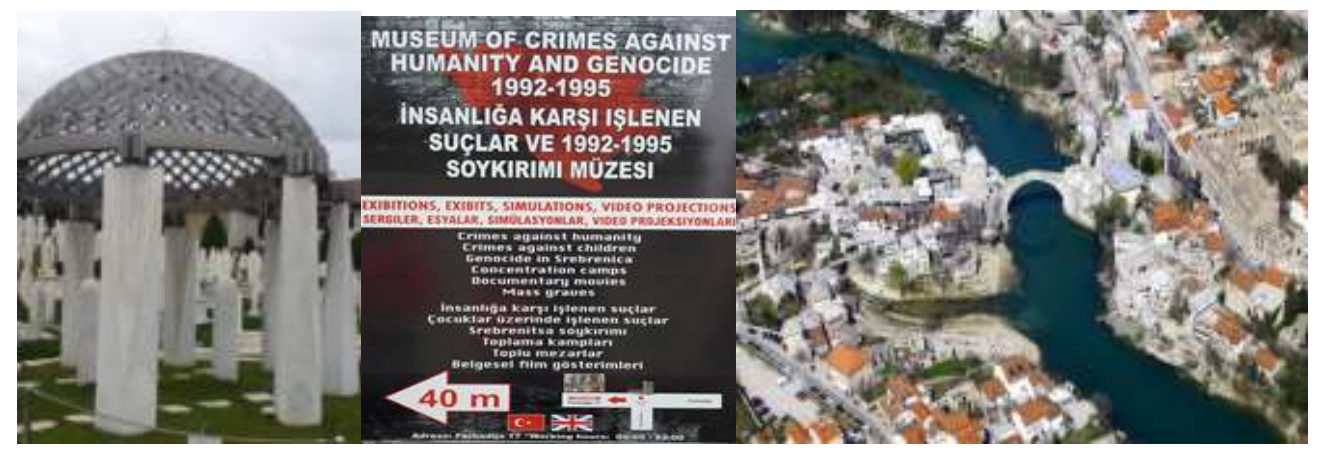

Fig. 20. Tomb of Alija Izetbegovic; Fig. 21. Museum of Crimes Against Humanity; Fig. 22. Mostar Bridge

14. Mostar Bridge: The "Old Bridge" stood for 427 years until it was destroyed on 9 November 1993, during the War in Bosnia and Herzegovina; reconstruction was completed in 2004. They recently revived the tradition of having a select few brave, skilled (and borderline foolish) young divers every year. The practice dates back to the time the bridge was built, and the first recorded instance of someone diving off the bridge is from 1664 (19).

\section{CONCLUSION}

As a kind of inheritance tourism, the Grief tourism, is visits to the places where death, violence, torture, presecution and pain lived. The attractions for grief tourism are the war zones, prisons, places where natural disasters, poverty, hurricanes occured.The war that took place in Bosnia and Herzegovina between 1992 and 1995, was the greatest tragedy of humanity that was seen after the second world war. During this war, ethnic cleansing and genocide were experienced in Bosnia and Herzegovina. Bosnia and Herzegovina that carries deep traces of war all over the country is the most sadness country of the Europe. The places where the massacres have taken place turned into places of remembrance of the loss of people lives, and become places of visit. However, the two sided management system in the country has significantly limiting the places to visit for grief tourism purpose. Attempts made to restrict the monuments used to commemorate victims in many places are a negatie situation and an obstacle for grief tourism especially when the foreign tourists intended to visit the places.

The contribution of tourism to certain location has significant economic and other effects.So Bosnia Herzegovina can use the grief tourism potential as a tool for 
economic development andto ensure employment. Currently, due to the intensive use of social media internationally and also in tourism, the centers of grief attract more attention and those places attracts more demand from muslim countries, especially from Turkey.The motivation factor to see, feel and remember, protect and to live the heritage of the ancestors is significantly effective on Turks. Setting peace and pieace of mind help collaboration and leverage effect for regional tourism development. Grief tourism, which is believed to be effective in increasing tourism demand for Bosnia and Herzegovina, may also bring about ultra nationalist sentiments. For that purpose it requires to be marketed with extreme caution.

The types of touris tours in Bosnia Herzegovina's tourism destinations are mainlythe cultural tours, and in these destinations the grief tourism form seen as dominant one. In those tours the attention of guides to the composion of tours' homogenity and hetoregenity is extremely important. In some tours, extremely intense emotions and hate speech are experienced. That type of approaches may harm the fragile structure in the region. Tourism, as a sensitive industry, requires stability in peace and security. Tourism may be an alternative option to reduce the intense unemployment level and economic difficulties experienced in the country. So, preserving the peace and security of the country is the most important issue.

\section{REFERENCES}

1. Akpınar A. (2006). Sarayova Osmanlının Bıraktığı Gibi Duruyor!, Bosna-Hersek Gezi Notları, Cumhuriyet Üniversitesi İlahiyat Fakültesi Dergisi, Cilt X/1, S.279285, Haziran, 279-285.

2. Blom, T. (2000). Morbid Tourism: A Postmodern Market Niche with an Example from Althorpe. Norwegian Journal of Geography 54:29-36.

3. Birdir K., Dalgıç A., Güler O. ve Kayaalp Y. (2015). Hüzün Turizmi: Gelibolu Yarımadası Tarihi Milli Parkını Ziyaret Eden Yabancı Turistlerin Deneyimleri, Journal Of Tourism And Gastronomy Studies 3/4 (2015) 12-23.

4. Bosna Hersek Sektör Raporları Turizm Sektörü, Türkiye Kalkınma Bankası A.Ş. Ekonomik veSosyalAraştırmalar Müdürlüğü, Ocak 2010 Ankara.

5. Dunkley, R. , Westwood, S. and Morgan, N. (2007). A shot in the dark? Developing a new conceptual framework for thanatourism, Asian Journal of Tourism and Hospitality Research 1 (1) 54-73.

6. Kılıç B. ve Akyurt H. (2011). Destinasyon İmajı Oluşturmada Hüzün Turizmi: Afyonkarahisar ve Başkomutan Tarihi Milli Parkı, Gaziantep Üniversitesi Sosyal Bilimler Dergisi (http://sbe.gantep.edu.tr) 2011 10(1):209-232.

7. Kılıç B.ve Kurnaz A. (2010). Alternatif Turizm ve Ürün Çeşitliliği Oluşturmada Ekolojik Çiftlikler: Pastoral Vadi Örneği, İşletme Araştırmaları Dergisi 2/4 (2010) 39-56. 
8. Kılıç B., Kurnaz H.A ve Sop A.S. (2011). Çekici Faktörlerin Destinasyon Seçimine Etkisinin Belirlenmesi ve Hüzün Turizmi İlişkisi, 12. Ulusal Turizm Kongresi, Akçakoca- Düzce, 362-370.

9. Kondo, S. (2003). Bosna-Hersek Coğrafyası, Ankara Üniversitesi Sosyal Bilimler Enstitüsü, Coğrafya (Türkiye Coğrafyası) Anabilim Dalı Bosna-Hersek Coğrafyası Yüksek Lisans Tezi,Ankara, 2003.

10. Kozak M.A. ve Bahçe A.S. ( 2012). Özel İlgi Turizmi, Detay Yayıncılık, Ankara.

11. Kurnaz H.A., Çeken H. ve Kılıç B.(2013). Hüzün Turizmi Katılımcılarının Seyahat Motivasyonlarının Belirlenmesi, İşletme Araştırmaları Dergisi (İsarder), 5/2, 57-73.

12. Malcom, N.(Çevr. Aşkım Karadağl1); Bosna’nın Kısa Tarihi, Om Yayınları, 1999.

13. Özder, A. (2012). Bosna-Hersek Cumhuriyeti‘nde Coğrafyanın Halk Kültürüne Etkisi, Marmara Coğrafya Dergisi No: 25, January, S. 213-237.

14. Robb, E.M., (2009).Violence and Recreation: Vacationing in the Realmof Dark Tourism, Anthropology and Humanism, Vol. 34, Issue 1, pp 51-60.

15. Seaton, A.V.(1996). Guided by the dark: From thanatopsis to thanatourism, International Journal of Heritage Studies, 2:4, 234-244.

16. Stone, P.R. (2006). A Dark Tourism Spectrum: towards a typology of death and macabre related tourist sites, attractions and exhibitions. Tourism: An Interdisciplinary International Journal, 54(2),145-160.

17. Stone,P. and Sharpley, R.(2008).Consuming Dark Tourism:A Thanatological Perspective, Annals of Tourism Research, Vol. 35, No. 2, pp. 574-595.

18. Stone, P.(2010).Death, Dying And Dark Tourism in Contemporary Society: A Theoretical And Empirical Analysis, Doctoral Thesis,University of Central Lancashire.

19. Türkeş, M., Rüma, Ş.İ, Akşit, S.(2012). Kriz Sarmalında Bosna Hersek Devleti: “Devlet Krizi”, Boğaziçi Üniversitesi Tüsiad Dış Politika Formu Araştırma Raporu, Dpf, Rr-02.

20. Y1ldız Z., Y1ldız S. ve Aytemiz L.(2015). Kara Turizm, Terör Turizmi ve Türkiye Potansiyeli, İnsan ve Toplum Bilimleri Araştırmaları Dergisi, Cilt: 4, Sayı: 2, 390407 itobiad-e-issn: 2147-1185.

21. Verma, S.And Jain, R.(2013). Exploiting Tragedy For Tourism, Research On Humanities And Social Sciences, Vol.3, No.8,pp. 9-13.

22. Winter, C.(2009). Tourısm, Social Memory And The Great War Annals of Tourism Research, Vol. 36, No. 4, pp. 607-626.

23. Rybakova E.V. (2012). Death And Dying In Contemporary Tourist Practice: Towards The Phenomenon Of Dark Tourism, Scientific Researches And Their Practical Application. Modern State And Ways of Development,

24. http://www.sworld.com.ua/index.php/ru/conference/the-content-ofconferences/archives-of-individual-conferences/oct-2012.

25. Rosenbaum A. (2006). Cultural Tourısm In Bosnıa \& Herzegovina, Prelımınary Findings, The United States Agency for International Development., USAID Bosnia \& Herzegovina Cluster Competitiveness Activity. 
26. Bordun O. and Komar R.(2014). "Current State and Prospects of Dark Tourism Flows Organization in Ukraine", Current Issues of Tourism Research.

27. Liyanage S., Stefaniak J. A. C. and Powell R. (2015). Dark Destinations - Visitor Reflections From A Holocaust Memorial Site, International Journal Of Tourism Cities J Vol. 1 No. 4 2015, pp. 282-298, Emerald Group Publishing Limited, Issn 2056-5607 Do1 10.1108/Ijtc-08-2015-0019.

28. Molokáčová L. And Molokáč S. (2011). New Phenomenon - Dark Tourism, Acta Geoturistica volume 2 (2011), number 1, 1-7.

\section{Internet References}

1. Yirik ve Seyitoğlu, http://docplayer.biz.tr/11317036-Huzun-turizmi-vemabetlesme-sureci-kapsaminda-sarikamis.html, Erişim Tarihi: 09.03.2016

2. http://haberciniz.biz/saraybosnanin-ilk-kurbani-kahraman-kadinlar-unutulmadi1968140h.html,

Erişim Tarihi: 09.09.2016 ;

Türbedar,Erhan, "YugoslavyaKrizininKronolojisi”,http://tarihbilgi.wordpress.com/2 008/10/17/Yugoslavya/ (e.t. 17.05.09) 2. http://www.balkangunlugu.com/tag/olgasucic

3. https://www.ihh.org.tr/haber/5-subat-1994-bosna-markale-pazaryeri-katliami-2092, Erişim Tarihi: 10.09.2016

4. http://www.dunyabulteni.net/?aType=haber\&ArticleID $=256170$, Erişim Tarihi: 01.10 .2016

5. http://www.timeturk.com/tr/2012/10/01/bosna-da-savas-kurbani-cocuklaranildi.html,ErișimTarihi:2.10.2016,http://www.dunyabulteni.net/?aType=haber\&Ar ticleID $=256170$, Erişim Tarihi: 30.09.2016

6. Danışman, E. Türbedar, Bir Savaşın Anatomisi Bosna Hersek: Bosna Hersek Adalet Arıyor,TRT INT, 29 Ağustos 2013; http://followhisdream.com/?p=1398, Erişim Tarihi: 30.09.2016

7. http://www.haber3.com/visegrad-katliaminin-23-yil-donumu3403511h.html,16.06.2012

http://www.pressmedya.com/?aType=haber\&ArticleID=9281: Erișim Tarihi $\underline{6.10 .2016}$

http://www.rubasam.com/NewsDetail.Asp?NewsID=35600, $\quad$ Erişim Tarihi: 29.09.2016

8. http://www.dailysabah.com/history/2015/07/10/exile-torture-and-masskillingsterrifying-crimes-of-thebosnian-war: Erișim Tarihi: 3.10 .2016

9. http://www.yenicaggazetesi.com.tr/srebrenitsa-soykirimi-21 inci-yilinda141568h.html,

Erişim Tarihi: 02.10.2016 
10. https://www.tumblr.com/search/srebrenica+massacre, Erişim Tarihi: 02.10.2016;Potoçari Anıt Mezarlığı'nın açılışının 10'uncu yıldönümü, http://www.turkiyegazetesi.com.tr/dunya/78494.aspx, Erişim Tarihi: 3.10.2016

11. http://balkanwitness.glypx.com/un-annex5-prijedor.html, Erişim Tarihi: 02.10.2016http://www.milliyet.com.tr/bosna-da-bir-olum kampi/pazar/haberdetayarsiv/02.07.2006/162648/default.htm Erișim Tarihi: 1.10.2016

12. https://genocideinbosnia.wordpress.com/tag/prijedor-genocide; Erişim Tarihi: 1.10 .2016 http://www.milliyet.com.tr/bosna-da-bir-olum kampi/pazar/haberdetayarsiv/02.07.2006/162648/default.html Erişim Tarihi: 03.10.2016

13. http://moracalan.blogspot.com.tr/2006/04/saraybosna-5-latin-kprs-28-haziran.html). Erişim Tarihi: 03.10.2016

14. http://www.haberbosnak.com/genel/19/01/2015/saraybosnada-evsizlerin-zorluyasami/\#.VqCGIVOLIhttp://www.gen4trip.com/en/sourcearticle/view?id=19407,Erişim Tarihi: 04.10.2016

15. http://www.telegraph.co.uk/news/worldnews/europe/bosnia/10819836/Sarajevoreopens-historic-city-hall-and-library-destroyed-in-war.html,Erişim Tarihi: 05.10 .2016

16. http://www.aljazeera.com.tr/haber/aliya-izzetbegovicin-mezarina-saldiri Erişim Tarihi: 06.10 .2016

17. http://www.gpsmycity.com/attractions/alija-izetbegovic-museum-54207.html Erişim Tarihi: 4.10 .2016

Erişim Tarihi: 06.10.2016

18. http://www.balkaninsight.com/en/article/sarajevo-crimes-against-humanitymuseum-opens-07-22-2016http://www.sarajevotimes.com/?p=104725, Tarihi: 07.10 .2016

19. http://www.iguzzini.com/projects/light-is-back/mostar-bridge/, Erişim Tarihi: 08.10 .2016 